\title{
AKAP4 Gene
}

National Cancer Institute

\section{Source}

National Cancer Institute. AKAP4 Gene. NCI Thesaurus. Code C142994.

This gene is involved in both sperm motility and protein kinase A binding. 